\title{
O poeta itinerante
}

\author{
Antonio Candido
}

"Louvaçăo da tarde", de Mário de Andrade, foi escrito em outubro de 1925 e publicado em 1930 como poema final da série denominada "Tempo da Maria", no livro Remate de males. Ele ocupa na sua obra uma posiçăo-chave, porque representa a passagem da poesia mais exterior dos primeiros tempos de luta modernista para a poesia mais interior da última fase.

Falando do poema numa carta a Manuel Bandeira, de 12 de dezembro de 1925, Mário de Andrade registra este caráter de transiçăo (para melhor segundo ele) e diz com humor que está fazendo poemas de leitura diffcil, cacetes, ao gosto dos ingleses pela extensăo, o cunho meditativo e a subordinaçăo a um esquema de pensamento, tendo por finalidade manifestar um lirismo mais profundo, menos comprometido com a notaçăo exterior e o pitoresco.

É oportuno lembrar que algum tempo antes havia escrito dois poemas também longos mas diametralmente opostos a este, sendo ambos construidos em torno de algo exterior ao poeta: "Carnaval carioca" (1923) e "Noturno de Belo Horizonte" (1924). O primeiro descreve o movimento colorido dos grupos e da multidăo; o segundo é uma espécie de rapsodia do Brasil através de Minas. A partir de "Louvaçăo da tarde" a sua poesia se construirá cada vez mais em torno do próprio eu, numa linha meditativa e analnica acentuada.

1.

O que deve ser sublinhado em primeiro lugar neste poema é o tipo de verso, tăo discrepante dos postulados modernistas e da conquista do verso livre. O decassllabo branco, usado aqui pela primeira e única vez na obra de Mário de Andrade, parece ter sido escolhido por mais de um motivo e significar mais de uma coisa.

Primeiro, mostra o desejo de empregar um metro cuja amplitude o torna equivalente do pentâmetro jâmbico usado em muitos dos poemas ingleses carregados de reflexăo, que desejou imitar. Segundo, a escolha parece marcar paradoxalmente o triunfo do modernismo, porque denota a confiança adquirida por quem é capaz de incorporar as conquistas expressionais e temáticas a um esquema do passado. Deste modo a presença do decasslabo assinala o momento de refluxo da libertinagem "de guerra", exterior e pitoresca, mostrando que a mensagem de vanguarda podia entroncar-se na tradiçấo $\Theta$, assim, encaixar-se na literatura brasileira. De fato, "Louvaçăo da tarde" remonta năo apenas aos poerras ingleses de tipo reflexivo com referência à natureza, mas às meditaçoes em verso branco da nossa literatura pré-romântica e romântica (Borges de Barros, Gonçalves Dias, Varela, Bernardo Guimarães). Caso interessante de poema moderno feito de maneira aparentemente antiga, ele é um momento-chave năo apenas na obra de Mário, mas na relaçăo entre modernidade e tradiçắo, marcando uma etapa importante no caminho do modernismo. Eis o que diz um trecho da carta a Manuel Bandeira:

Agora meu desejo é esse: construir o poema pau, o poema que năo tem nenhuma excitaçăo exterior, nem de pândega, nem de efeitos nenhuns nem de
ANTONIO CANDIDO é protessor aposentado de Teoria Literária e Literatura Comparada da FFLCH-USP, e autor de Formaçấo da literatura brasileira. Seu livro mais recente ế a coletanea de ensaios $A$ educaçáo pela noite (Editora Ática). 
sentimentos vivazes. Nada que flameje, que rutile, que espicace. Nada de condimentos nem de enfeites. O poema poesia construído com pensamento condicionando o lirismo que tem de ser enorme (senăo năo transparece) o mais formidável que puder porém duma ardência como que escondida porque inteiramente interior. Enfim: o poema ingless. Shelley, Keats, Wordsworth, Swinburne, Yeats, essa gente. Pleiteio por Álvares de Azevedo contra Castro Alves, caso típico de poesia excitante, poesia condimento, poesia cocktail, poesia-coisa-assim. Quero construir o poema que năo se pode ler no bonde, o poema que năo pode ser recitado (o tempo dos rapsodos e dos menestrés já passou) o poema que carece ser lido, entendido e o amor verdadeiro há-de descobrir dentro dele o fogo e o foco ardent'ssimos porém que năo queimam, em vez elevam consolam e săo fecundos ${ }^{(1)}$.

Estas indicaçర̋es săo valiosas, inclusive porque nem sempre temos a reflexăo de um poeta sobre os seus poemas, e elas mostram de que modo Mário de Andrade procurava ligar o texto a uma genealogia.

A sua construçăo ế rigorosa, adequada ao propósito expresso na carta a Manuel Bandeira: fazer uma reflexẫo organizada por meio de idéias encarnadas no lirismo. No entanto o discurso ê aparentemente casual, dando a impressăo de obedecer às associaçర్లs, como se a palavra seguisse o movimento caprichoso de um passeio. Correspondendo a isto a formula versificatória tradicional e estrita é manipulada de modo liberto, segundo uma dicçăo fluente de ritmo coloquial. A modemidade é evidente nessa maneira folgada de usar o decasslabo, em combinaçoes que rompem o esquema métrico, ora picadas em unidades Infimas, ora espraiadas em longas emissర̋es que ultrapassam vinte slabas. O ritmo e o vocabulário săo os da prosa familiar, bem próximos do dia-a-dia, distantes da solenidade que o metro poderia sugerir. É um admirável monólogo em tom de conversa fiada onde o tempo narrativo equivale ao tempo narrado, desdobrando-se enquanto o emissor do discurso vai indo de automovel por uma estrada ao por-do-sol. O deslocamento no espaço e a contemplaçăo da paisagem se associam para estimular a mente, que se pð̄e a pensar e a devanear, repassando o próprio modo de ser, os projetos, as aspiraçס̄es. Enquanto isso a tarde cai, ele chega de volta à casa da fazenda e a lua aparece. A análise minuciosa levaria longe, por isso farei apenas uma descriçăo crftica, começando por indicaçōes que permitam estabelecer o laço entre "Louvaçăo da tarde" e certas modalidades de poesia romântica.

2.

O poema reflexivo dos românticos, chamado algumas vezes "meditaçăo", difere essencialmente dos poemas de cunho filosófico dos neoclássicos denominados "eplstola", "ensaio", etc., verdadeiras dissertaçర్es em verso sobre um tema abstrato, um acontecimento, como o "Ensaio sobre o homem", de Pope, ou o "Poema sobre o desastre de Lisboa", de Voltaire, sem falar nos puramente didáticos.

O que os prê-românticos e os românticos fizeram foi algo ligado à experiência sensorial e afetiva, dissolvendo a dissertaçāo num discurso que a transformava em "modo" da sensibilidade. Em vez de partirem de um conceito, julzo, afirmaçăo, partiam de algum estimulo dos sentidos ou do sentimento, devido geralmente à contemplação da natureza, que dava corpo palpável à generalidade das abstraçס̄es. A natureza tornava-se correlativo do pensamento e do sentimento, permitindo a ligaçăo intima com a subjetividade.

No pré-romantismo, sobretudo ingiês, isto começa pelo vinculo entre a reflexão e o lugar. Exemplo é a "Elegia escrita num cemitério campestre", de Thomas Gray, onde a presença física do cemitério, descrito com pungência e melancolia, instiga a refletir sobre a morte relacionada à condiçăo humana (como faria de certo modo Paul Valéry n' "O cemitério martimo"). Note-se que neste caso a relaçăo entre o emissor do discurso e a natureza ê estática. Mas "Louvação da tarde" pertence a outra chave, a da relaçăo dinâmica, na qual o emissor do discurso se movimenta, configurando o que poderfamos chamar "poesia itinerante". Trata-se da funçăo poética da marcha, o corpo em movimento servindo para espertar a mente.

Um precursor disto, como de tantas coisas do romantismo, foi Jean-Jacques Rousseau, ao vincular o sentimento da natureza, a meditaçăo e o movimento do corpo nos Devaneios do pas. seante solitário, dez meditaçōes (em prosa) sobre os mais variados temas, chamadas significativamente "passeios". Embora o autor năo esteja o tempo todo no ato de andar, é básica a idéia de que a caminhada desperta a reflexăo a partir das emoçס̋es, tendo como catalisador o espetáculo 
da natureza. O livro de Rousseau é um marco na formaçăo do romantismo e um exemplo que ajuda a entender a atmostera espiritual que gerou a poesia itinerante.

Muito ilustrativo é ó caso de Wordsworth, poeta ambulante por excelência, que logo no começo da atividade poética escreveu "Um passeio vesperal" (An evening walk), de corte meramente descritivo. A meditaçăo reponta mais noutro poema de mocidade, "Esboços descritivos" (Descriptive sketches), onde fala dos "prazeres do viajante a pe" num sumário que precede os versos. Este poema é uma longa descriçăo de viagem pelos Alpes, ligando a cada instante a reflexăo ao deslocamento no espaço e ao espetáculo da natureza, processo freqüente em Wordsworth $\theta$ um dos apoios do seu enorme, cacet/ssimo poema chamado significativamente "A excursăo" (The excursion), onde focaliza problemas do homem e da sociedade, inclusive os da Revoluçăo Francesa, que primeiro o fascinou, depois o desiludiu.

Năo apenas em Wordsworth, mas noutros românticos de diversos palses a poesia itinerante foi renovadora, exprimindo a nova correlaçăo entre homem e natureza, na medida em que aumentava a intimidade entre ambos e assim permitia a expansăo mais direta da individualidade. A

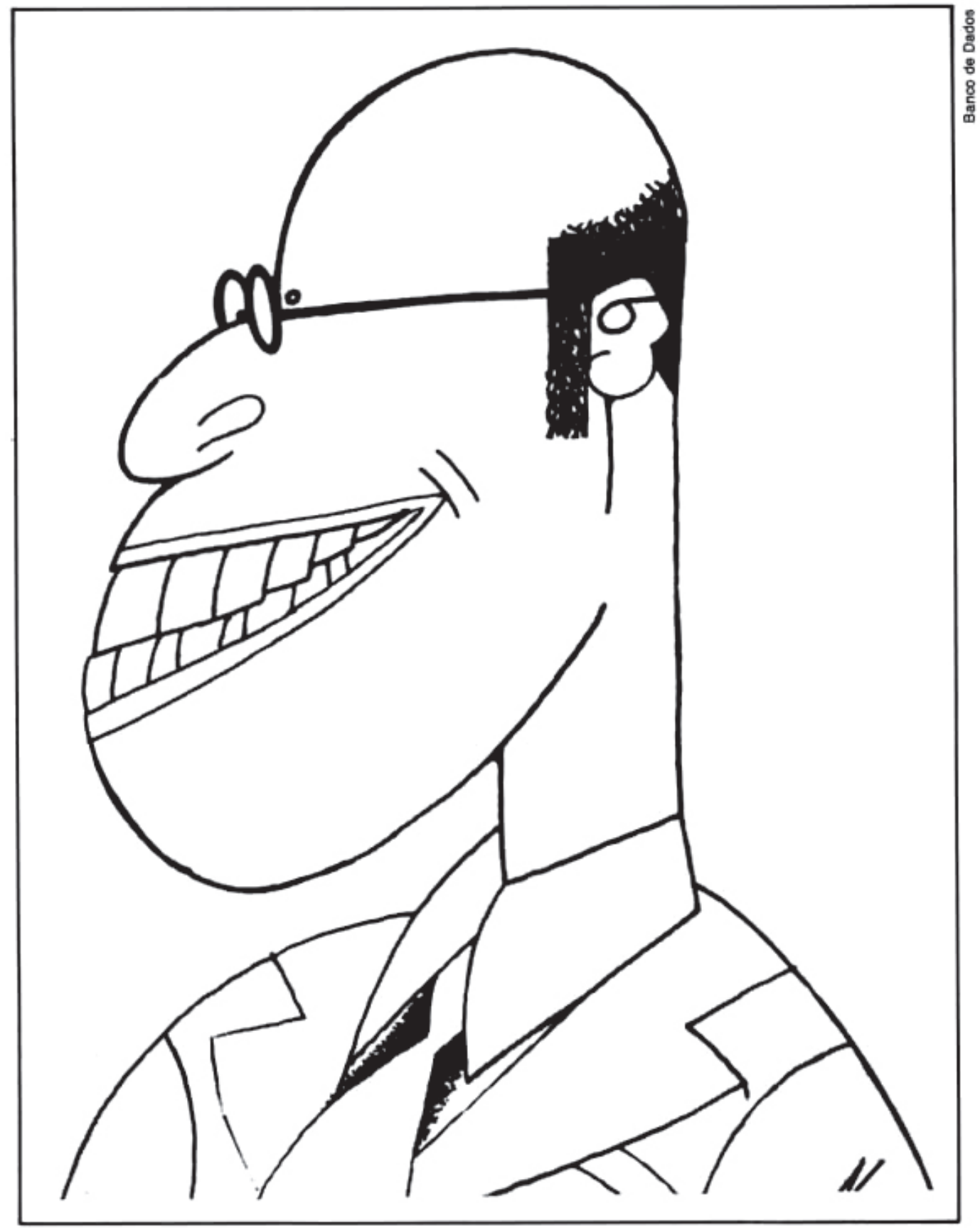

Caricatura de Mário de Andrade, por Nássara (1934); nanquim sobre papel 
natureza, penetrada diretamente no percurso, tornava-se algo proximo do poeta, que se valia dela para abordar os temas mais variados, inclusive a concepçấo de poesia, como acontece em "Sub tegmine fagi", de Castro Alves, caminhada pelo campo e a floresta que serve de ocasiåo para refletir poeticamente.

À poesia itinerante devernos associar outra modalidade que pode ser qualificada como "poesia de perspectiva", na qual a meditação, sucedendo a uma andança implicita, é feita a partir da altitude, como ocorre freqüentemente no próprio Wordsworth. Lembremos certas composiçס̋es de Lamartine, nas quais a meditaçăo nâo deriva do deslocamento no espaço, mas do movimento da visão a partir de um lugar alto. É o caso de $L$ 'isolement, iniciado com o olhar percorrendo a paisagem:

Souvent sur la montagne, à l'ombre du vieux chêne,

Au coucher du soleil, tristement je m'assieds;

Je promène au hasard mes regards sur la plaine,

Dont le tableau changeant se déroule à mes pieds.

Lembremos ainda o curto e denso L'infinito, de Leopardi, construldo a partir de uma idêntica visăo da altura:

\section{Sempre caro mi fu quest'ermo colle.}

"Louvaçăo da tarde" participa da primeira modalidade: ê uma meditaçăo ambulante, sendo o único poema de Mário de Andrade onde encontramos a combinaçâo "natureza-passeio-meditaçăo". Ele escreveu numerosos outros poemas itinerantes, mas figurando caminhadas urbanas $e$ se entroncando por af numa tradiçăo do romantismo tardio. Vale a pena dizer uma palavra sobre esta tradição derivada, presa à intensa urbanizaçăo do mundo contemporâneo.

Sabemos que para muitos a modernidade começa com a obra de Baudelaire, que instaurou a poesia da grande cidade, inclusive do ângulo do passeador, estudado por Walter Benjamin num tópico do ensaio "Paris, capital do século XIX" e, mais detalhadamente, nos "Temas baudelaireanos", onde aborda sobretudo a multidăo. Em Baudelaire a grande cidade foi transformada numa espécie de nova paisagem que substitui a natural.

Săo muitos os poetas e prosadores que trabalharam sobre esta metamortose, chegando alguns a uma poesia densa e cheia de fantasia, como foi o caso de Louis Aragon no surrealismo. Seu livro Le paysan de Paris, talvez inspirado pelos poemas em prosa de Baudelaire, cria uma espécie de nova naturalidade, de nova espontaneidade no quadro artificial e mecanizado da metrópole, tratada como fonte de um fantástico que a imaginaçăo descobre nas dobras do quotidiano. E lembremos que um dos poemas mais importantes do século XX, "A terra desolada", de T. S. Eliot, é uma espécie de transposiçăo de buscas alegóricas para o quadro da cidade grande, jâ cantada por ele em poemas anteriores, como "A cançăo de amor de J. Alfred Prufrock", que começa ligando o itinerário à reflexăo, num cenário onde a natureza foi substitulda pelo ambiente urbano:

Sigamos então, tu e eu,

Enquanto o poente no céu se estende

Como um paciente anestesiado sobre a mesa;

Sigamos por certas ruas quase ermas,

Através dos sussurrantes refúgios

De noites indormidas em hotéis baratos,

Ao lado de botequins onde a serragem

As conchas das ostras se entrelaça;

Ruas que se alongam como um tedioso argumento

Cujo insidioso intento

É atrair-te a uma angustiante questẫo...

(Trad. de Ivan Junqueira)

$\mathrm{Na}$ literatura brasileira anterior ao modemismo há pelo menos um notável exemplo de meditaçăo itinerante na moldura transfigurada das capitais: "As cismas do destino", de Augusto dos Anjos, fala desvairada e eletrizante no decurso de um passeio noturno rumo a certa casa funerá. ria, que começa assim:

Recife. Ponte Buarque de Macedo.

Eu, indo em direçăo à casa do Agra,

Assombrado com a minha sombra magra,

Pensava no Destino e tinha medo! 
Mário de Andrade praticou em toda sua obra a poesia da rua e do poeta andarilho, frequeentemente nas horas da noite, marcadas pela inquietaçăo e mesmo a angústia. Mas em "Louvaçăo da tarde" está noutra chave, próxima daquela serenidade contemplativa dos primeiros românticos, como alguém que procura sobretudo a paz pela meditaçăo serena no quadro natural.

3.

Meditaçăo da mais completa modernidade, seja dito, a começar pelo fato do poeta năo ir a pé, como o viajante de Wordsworth, o flâneur de Baudelaire, o notâmbulo alucinado de Augusto dos Anjos ou os personagens tresmalhados de Eliot. Nem a cavalo (apesar de estar no campo), como Julian e Maddalo no poema onde Shelley figurou a si proprio e a Byron sob estes nomes. Em "Louvaçăo da tarde" o poeta vai de automovel, que designa por um diminutivo carinhoso e trata como ser vivo, pois em vez de dirigi-lo abandona-se a ele, ao modo de montaria confiável cujas rédeas foram soltas:

\section{E a maquininha me conduz, perdido \\ De mim, por entre cafezais coroados, \\ Enquanto meu olhar maquinalmente \\ Traduz a lingua norteamericana \\ Dos rastos dos pneumáticos na poeira.}

Trata-se portanto de uma meditaçăo itinerante entrosada na era da mecanizaçăo, e tanto quanto sei é a primeira onde o deslocamento no espaço se faz por este meio. É claro que há poe-

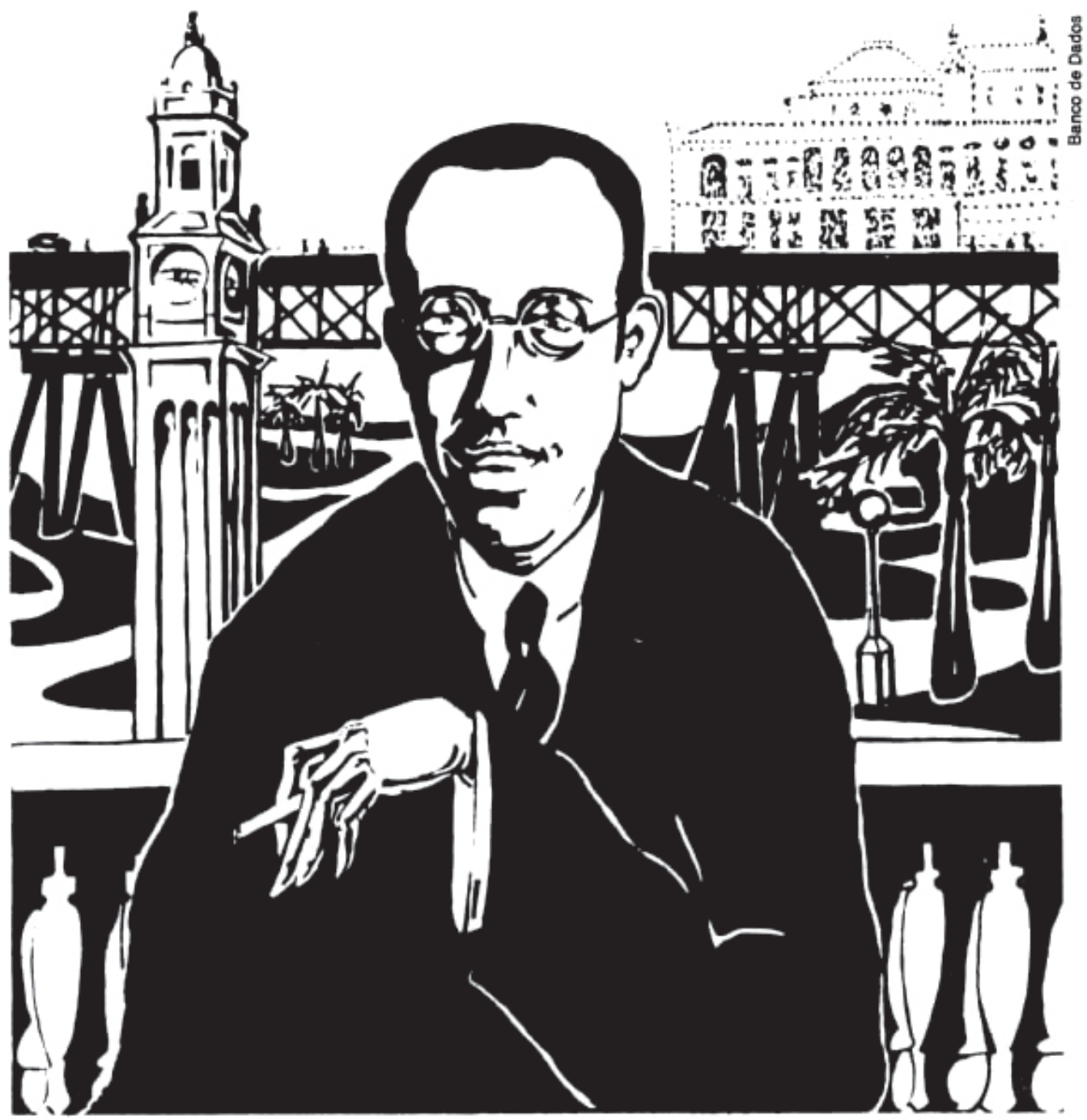

"Retrato de Mário de Andrade", de Zina Aita (1923); nanquim sobre papel 
mas anteriores nos quais o automovel aparece, mas năo conheço outro onde esteja em contexto semelhante, isto é, o do poema-meditaçăo. Creio que Mário de Andrade realmente "inventou", ao aproveitá-lo como traço moderno inserido em texto de ressonância tradicional, gerando a modernidade através de uma atitude quase paródica. Lembro que é posterior, de 1928, o curto poema em versos livres no qual Fernando Pessoa (Álvaro de Campos) narra uma excursăo noturna "ao volante do Chevrolet", durante a qual expð̄e as emoçðes do momento.

Enquanto objeto de poesia o automovvel já estava em diversos poemas de Marinetti. Por exemplo "Ao autombvel de corrida" (All'automobile da corsa), que glorifica a velocidade por meio da máquina, dentro do típico espirito futurista:

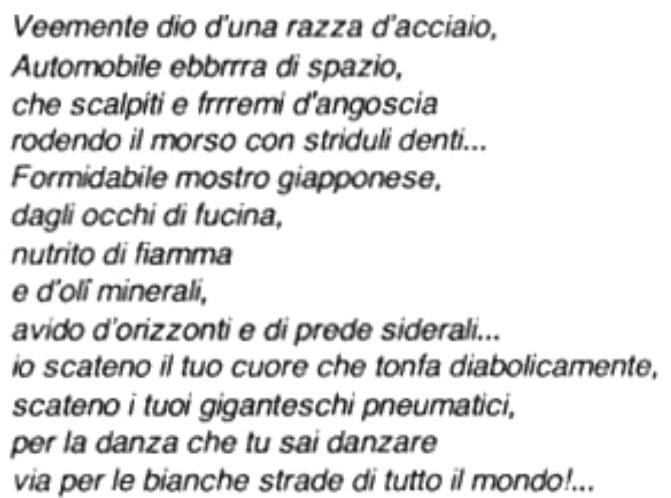

Faço a citação sobretudo para mostrar a diferença, indicando um segundo nivel da invençâo de Mário de Andrade: nos modernismos europeus, sobretudo o futurismo, o automovel estava ligado à potência da velocidade, à vertiginosa conquista do espaço, como sinal da nova era. Marinetti escreveu em 1909 no "Manifesto futurista": "(...) o esplendor do mundo foi enriquecido por uma beleza nova: a beleza da velocidade". E elevou este conceito a verdadeira teoria noutro manifesto, de 1916, intitulado "A nova religiăo-moral da velocidade". Como agente desta é que o automóvel era geralmente celebrado. Mas neste poema de Mário de Andrade ele aparece despido dos sinais vanguardistas de identificaçăo. Como verdadeiro figurante de poesia Ifrica romântica é doce, meigo, lento, assimilado a um animal integrado no ritmo da natureza. Talvez por isso o poeta crie um neologismo significativo para qualificâ-lo, nesta apßstrofe à tarde pacificadora:

\author{
Só no exnio \\ De teu silêncio, os ritmos maquinares \\ Sinto, metodizando, regulando \\ O meu corpo. E talvez meu pensamento...
}

Observe-se que os ritmos não săo "maquinais", isto é, automáticos, próprios de um mecanismo cujos movimentos săo prescritos e invariáveis, mas "maquinares", como "cavalares", "muares", próprios de máquina animalizada, e por isso mesmo se comunicam ao corpo do homem, funcionando como pulsăo reguladora. Hâ pois uma inversăo do clichê futurista, a fim de que a máquina típica das vanguardas no começo deste século possa ser incorporada ao ritmo eterno da natureza. É uma segunda invençăo, que descarta a filosofia da velocidade $e$ insere os seus emblemas no contexto contemplativo da tradiçăo, usada para sugerir a constância das obsessర్es poéticas.

Estamos portanto diante de um exemplo de fusăo de perspectivas, épocas, processos, jus tificando o ponto de vista que este poema é um momento de viragem e maturaçăo năo apenas na obra de Mário de Andrade, mas do próprio modernismo brasileiro, cuja fase de guerra estava começando a se estabilizar. No caso, pela transposiçāo de práticas literárias cuja origem é em boa parte romântica.

Mas fique claro: não se trata de recuo ou apostasia, e sim de uma demonstraçăo de validade do modernismo por meio do seu entroncamento na tradiçăo. De fato, este poema consolida a ruptura, ao provar que ela garante a perenidade dos valores, desde que estes se reencarnem nos requisitos da modernidade. Sob este aspecto, a espécie poética ("meditação") e a fómula métrica nunca usada por Mário de Andrade antes nem depois (decasshabo branco) assumem um ar de amena parodia, confirmada a cada passo pelo teor do discurso, cheio de humor e bonomia. 
4.

"Louvaçăo da tarde" se relaciona com outros poemas do autor. Principalmente dois, que formam com ele os pilares de uma trajetória: "Louvaçăo matinal", pouco posterior, e "A meditaçăo sobre o Tiete", do fim de sua vida.

Comparando-os percebemos uma funçăo diferente das horas do dia. Em "Louvaçăo matinal" a manhă corresponde à vida consciente e à luta diária. É o momento da vontade e da razăo. A noite d" "A meditaçắo sobre o Tietê" sintetiza todas as noites da poesia de Mário de Andrade e corresponde entre outras coisas à vida recalcada, aos desejos irregulares, ao inconsciente que assusta e a tudo o que a sociedade oprime. É o momento das rebeldias e dos impulsos arriscados. Situada entre as duas, a tarde do nosso poema é o momento do sonho e do devaneio, quando a pessoa concede a si mesma o direito de imaginar qual seria a sua melhor forma, e a imaginaçăo procura afeiçoar o mundo à veleidade. Momento da contemplaçăo serena, pressupondo o esforço de paz interior.

Instalado no volante do automóvel, um pequeno Ford dos anos 20, o poeta mal pressiona o acelerador e vai devagar, ajustando o ritmo do pulso ao ritmo da máquina, parando de vez em quando . O deslocamento no espaço e a intensa contemplaçăo da paisagem rural fazem dele um Wordsworth entre cafezais, com o passeio suscitando a meditaçăo longa e elaborada. Nesse poema tranqüilo, em paz com o destino, nascido nos momentos de intervalo da luta pela vida, ele repassa o seu modo de ser, os seus desejos, os seus projetos, misturando o devaneio à açăo imaginada, numa construçăo regular em cinco movimentos e uma conclusăo, sendo que o primeiro e o quinto parecem o mesmo, interrompidos estrategicamente pela intercalaçăo enriquecedora de exemplos que ilustram e encarnam a proposta central. Esta concerne a importância da imaginaçăo e do sonho como arsenais da criaçâo e do comportamento; as partes intercaladas aludern à necessidade da fantasia para construir uma plenitude fictícia, que compensa as frustraçסes da vida diária e ê chamada a certa altura a "mentirada gentil do que me falta".

Dentro do espirito de referência à tradiçăo, o começo do poema é uma curiosa encarnaçăo antropomorfica, personificando a tarde como se fosse entidade mitologica:

Tarde incomensurável, tarde vasta,

Filha de Sol jâ velho, filha doente

De quem despreza as regras da Eugenia,

Tarde vazia, dum rosado pálido,

Tarde tardonha e sobretudo tarde

Imovel...

O tom é de paródia divertida: no fim do dia o Sol, já velho e cansado da tarefa diária, engendra uma filha, a Tarde, frágil, melancólica, insatisfatória ante os requisitos da Eugenia, que naquele tempo andava em grande voga no Brasil. Esta filha enfermiça de velho é lerda, "tardonha". Assim, logo no início o vinculo com a tradiçăo é efetuado năo sơ por meio do decassłabo em pleno movimento de vanguarda, mas também por meio desta figura mitológica em chave humorística.

É visivel que o poeta se situa com certa passividade em face da paisagem, como quem vai sofrer a sua influência. A tarde o separa do tumulto quotidiano e assim cria condiçס̃es para ele se concentrar, superando a dispersão imposta pelas tarefas. É uma situaçăo ideal de independência que permitirá a liberdade da mente, inclusive porque o poeta se ajusta ao ritmo libertador da natureza, que o desliga da condiçấo de homem integrado nas obrigaçő́es da cidade. Isso começa pela homologia entre máquina e pássaro, pois o automóvel entra em uníssono com eles e deste modo se funde na natureza. Em conseqũência o ritmo mecânico é identificado ao ritmo natural e o corpo ganha intimidade com a paisagem, pela mediaçăo paradoxal da máquina humanizada. A ansiedade desaparece e o poeta esposa as coisas naturais, física e mentalmente:

O doce respirar do forde se une

Aos gritos ponteagudos das graúnas,

Aplacando meu sangue e meu ofego.

Ocorre entăo uma espécie de suspensăo do tumulto da vida, o ser se reorganiza e ele adquire maior lucidez, compreendendo que a suspensăo criada pela tarde deixa perceber uma linha de maior coerência no que realiza, fato que a dispersâo do dia não permitira ver. Isto se traduz, encerrando o primeiro movimento, numa imagem rural: os elementos dispersos da atividade, aparentemente desconexos, ganham sentido e parecem unir-se pela meditaçăo, do mesmo modo que o gado espalhado nos pastos é reunido à tarde nos currais: 


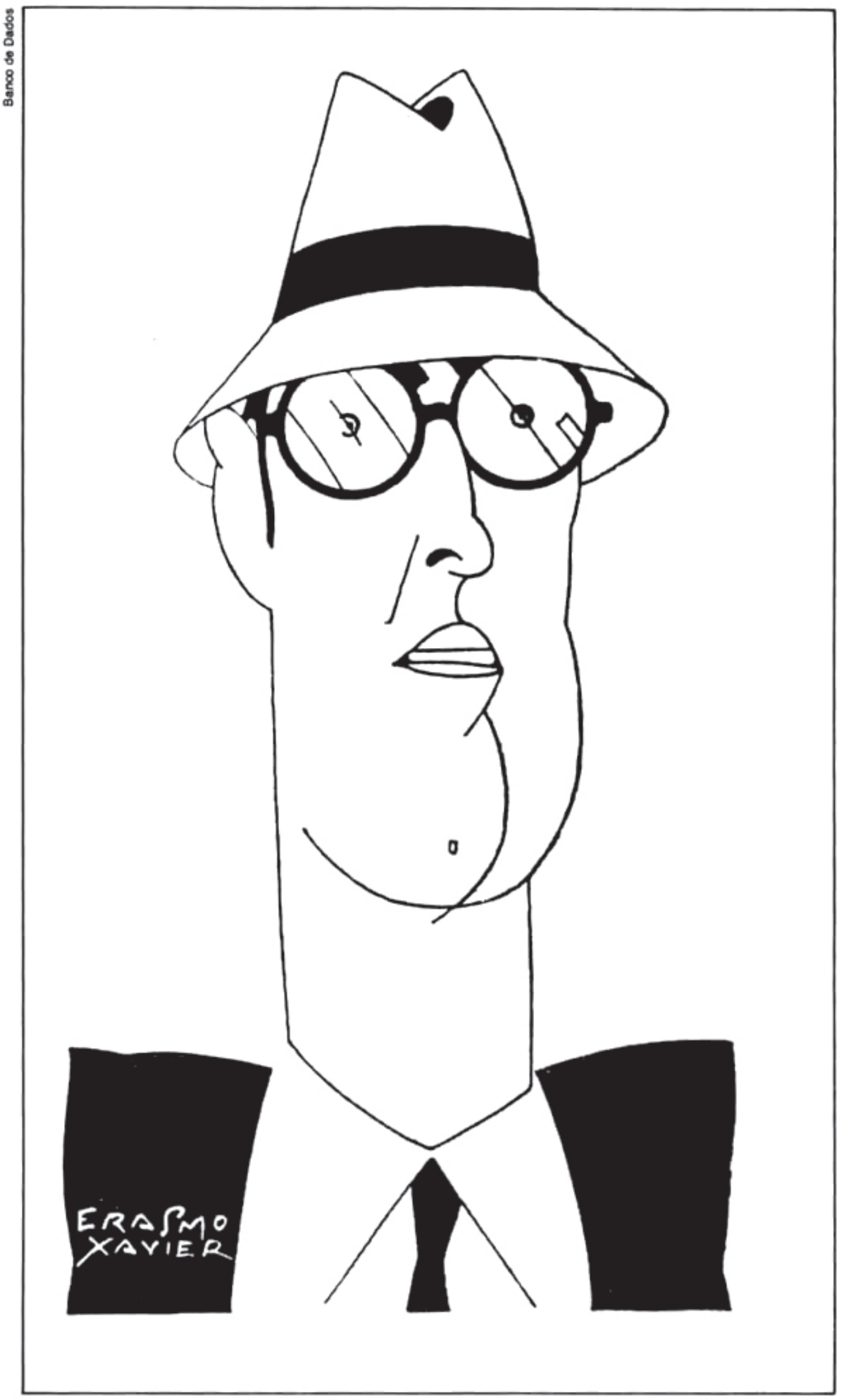

"Mário de Andrade - caricatura". de Erasmo Xavier (s/d); nanquim sobre papel 
Só nessa vastidấo dos teus espaços,

Tudo o que gero e mando, e que parece

Tăo sem destino e sem razăo, se ajunta

Numa ordem verdadeira... Que nem gado,

Pelo estendal do jaraguá disperso,

Ressurge de tardinha e, enriquecido

Ao aboio sonoro dos campeiros,

Enriquece o criador com mil cabeças

No circo da mangueira rescendente...

A tarde possui força pacificadora e unificadora, porque nela a imaginaçăo se liberta e pode criar uma forma paralela de atividade: o exercicio da fantasia. No caso, através do devaneio, que compensa as limitaçбes da vida corrente e deixa entrever uma outra, mais satisfatoria, que poderia cumular os desejos:

Nâo te prefiro ao dia em que me agito,

Porém contigo é que imagino e escrevo

$O$ rodapé do meu sonhar, romance

Em que o Joaquim Bentinho dos desejos

Mente, mente, remente impávido essa

Mentirada gentil do que r $r e$ falta.

Quando o poema foi escrito estes versos nâo precisavam de esclarecimento, porque os leitores estavam familiarizados com o personagerr caipira de Cornélio Pires, o mentiroso monumental do livro Estramboticas aventuras de Joaquim Bentinho, o queima campo (1925). A "mentrada gentil" procura compensar as limitaçరes, e é posslvel por ser a tarde a hora em que o trabaIho acabou e o protagonista está so, entregue a si mesmo. A tarde permite assim criar uma "outra vida", objeto dos tres movimentos seguintes, nos quais o poeta imagina realizaçઢes no plano do afeto, no do conhecimento do Brasil e no do bem-estar económico.

O segundo movimento, primeiro destes tres intercalados, começa com versos eutoricos:

...Toda dor ffisica azulou... Meu corpo,

Sem artritismos, faringites e outras

Especfficas doenças paulistanas,

Tem saúde de ferro.

No mundo do devaneio o poeta é forte, saudável, bonito, chegando a superar as frustraçסes amorosas. E aqui ocorre um jogo interessante entre o novo ser idealizado, integro, e a presença incormoda da realidade se infiltrando nele. Lembremos que "Louvaçăo da tarde" é a peça final do ciclo "Tempo da Maria", que descreve o amor impossivel por uma mulher casada e virtuosa. Graças à libertaçăo das contingências, permitida pela tarde, isto é, graças à fantasia do devaneio, o poeta se figura como alguém suficientemente forte para dominar a paixăo, "arquivar Maria" (como diz noutro poema) e cultivar apenas amores fáceis, sem consequêencias. Mesmo porque (movimento de raposa ante as uvas inacessiveis) ela năo era tăo bonita assim ("Qual!... Nem por isso. Năo sonho sonhos vắos") e sô traria problemas. Livre da obsessăo de Maria, a vida dele seria um "livro de aventuras", jogo de palavras misturando "aventura" =caso amoroso e "aventura"=ocorrências excitantes. Dentro de tal livro (a sua nova vida) Maria seria guardada ao modo de flor ou folha, entre páginas onde secaria e ficaria apenas como lembrança sentimental. Mas af ocorre um efeito poético todo sintese e alusấo: a evocaçăo da amada traz a sua presença para dentro do devaneio e a disposiçăo fraqueja, o que se exprime pelo subentendido das reticências. Maria será uma simples folha seca... Folha seca?... Será? Se a malva guarda o pertume, ela pode guardar a sua perturbadora realidade e parece emergir triunfante da metáfora:

Desejemos so conquistas!

Um poder de mulheres diferentes,

Meninas-de-pensåo, costureirinhas,

Manicuras, artistas, datilografas,

Brancaranas e biras sem escândalo,

Desperigadas... um livro de aventuras

Dentro do qual secasse a imagem da outra,

Que nem folha de malva, que nem folha

De malva... da mais pura malva pertumada!...

A euforia do devaneio tropeça portanto um momento, porque a malva parece teimosamente 
viva em vez de secar. Mas é só um momento. O poeta o contorna e vai à frente, na faina de construir a vida nova por meio do sonho, entrando no terceiro movimento do poema com a visăo da sorte melhorada que imagina:

Livre dos piuns das doenças amolantes, Com dinheiro sobrando, organizava

As poucas viagens que desejo...

Este movimento define o tema do Brasil, quase obsessivo na poesia de Mário de Andrade sob diversos avatares. Sucedendo imediatamente à evocaçăo dos amores, a referencia à sua terra dá idéia de transferência, como se o apego à pátria fosse um outro modo de fixar a afetividade. Seja como for, aparece agora um elemento importante da sua vida $\theta$ da sua obra: o gosto pelas viagens no pals, que chegou a conhecer bastante apesar das dificuldades de locomoçăo do seu tempo. Esse gosto aparece aqui como pena por nâo haver seguido a Coluna Prestes (referida indiretamente), cuja imensa peregrinaçăo estava se desenvolvendo quando o poema foi escrito:

$$
\text { ... se acaso }
$$

Tivesse imaginado no que dava

A Isidora, nẫo vê que ficaria

$\mathrm{Na}$ expectativa pança em que fiquei!

"Isidora" é a Revoluçăo de 1924, chefiada pelo general Isidoro Dias Lopes, que "deu" na guerrilha da Coluna Prestes através do sertăo brasileiro até fevereiro de 1927, quando os combatentes se internaram na Bollvia. 1927 foi o ano em que Mário de Andrade viajou pelo Amazonas até Iquitos, no Peru, sua única passagem fugaz e ocasional por terra estrangeira. No poema assinala que pagou a excursão com o dinheiro ganho nas tarefas literárias $\theta$ artísticas, nutridas pela imaginaçăo, prima do devaneio que a tarde encarna:

Tarde, com os cobres feitos com teu ouro

Paguei subir pelo Amazonas...

É engenhosa a combinaçăo dos metais, derivando paradoxalmente o menos nobre, isto ê, o "cobre" metonimico=dinheiro, do mais nobre, o "ouro" metafórico nascido do devaneio=tarde. (Estes versos mostram também que o poema foi retocado antes da publicaçăo no ano de 1930 , pois a viagem amazônica foi em 1927.)

O Amazonas tem papel importante na poesia de Mário de Andrade, correspondendo entre outras coisas aos impulsos primitivos do ser e da cultura. Correspondendo ao que há de dúbio na mente, como se o mistério da personalidade se exprimisse pela ambigüidade das paragens onde a terra confunde-se com a água, o mato grosso esconde tudo e a criaçăo parece inacabada. $\mathrm{E}$ a Amazônia faz o poeta pensar no Brasil inteiro, igualmente impreciso e amblguo, pátria "despatriada", neologismo pelo qual caracteriza a naçăo inorgânica cujo significado procura, como procura o dele próprio:

$$
\text { Mundos }
$$

Desbarrancando, chăos desbarrancados, Aonde no quiriri do mato brabo

A terra em formaçăo devora os homens...

Este refrăo dos meus sentidos... Nada

Matutarei mais sem medida, Oh tarde,

Do que esta pátria tăo despatriada!

Este momento de aventura e perplexidade contrasta com os versos do movimento seguinte, que começa por uma exclamaçăo:

Vibro! Vibrol Mas constatar sossega

A gente. Pronto, sosseguei. O forde

Recomeça tosando a rodovia.

Assim entramos no segmento final do devaneio, quarto do poema, agora referido à prosperidade económica expressa nos termos paulistas dos anos 20 , com base na lavoura do café e na pecuária do civilizado gado caracu:

Um sftio

Colonizado, sem necessidade

De japoneses nem de estefanoderis...

Que me desse umas quatrocentas arrobas...

Já bastava. Gordas invernadas

Pra novecentos caracus bem... 
Como está na hora de voltar à sede da fazenda, a imaginaçăo solta um último vơo e o poeta figura a casa que desejaria ter no sfitio imaginário, onde receberia os amigos e teria confortos sensacionais para o tempo, como aparelho de rádio capaz de captar Buenos Aires e Nova York. Isto feito, retoma a meditaçấo inicial, cujo nó está no verso

De-dia eu faço, mas de-noite eu sonho,

que sintetiza a filosofia do poema, explicando o significado da tarde: ela permite relacionar o sonho e a açăo, a vida contemplativa $\Theta$ a vida ativa, ressalvando o poeta que esta última é a mais importante, porque nela traça as normas do proprio destino e as obedece com tenacidade. No entanto a vida contemplativa do sonho é um hiato indispensável que reequilibra o ser, porque permite compensar a frustraçăo pelo projeto, liberando a quota de fantasia que se transforma em combustivel da atividade. O sonho distingue o plano ideal do plano real (isto é, o céu e a terra), abrindo espaço para a imaginaçăo subir bem alto, ao modo do vớ do jaburus. Assim a tarde reabastece a energia consumida pelo dia e reequilibra a relaçăo entre realidade e fantasia criadora, essencial para o trabalho do poeta, que sem o material sonhado nâo atinge o ato, isto é, a realizaçăo da obra. Por isso louva a tarde que o ajuda a se reequilibrar depois da faina do dia:

Tarde do meu sonhar, te quero bem!(2)

Deixa que nesta louvaçăo se lembre

Essa condescendencia puxa-puxa

De teu sossego, essa condescendência

Tâo afeiçoável ao desejo humano.

De-dia eu faço, mas de-tarde eu sonho.

Năo és tu que me dás felicidade,

Que esta eu crio por mim, por mim somente,

Dirigindo sarado a concordancia

Da vida que me dou com o meu destino.

Năo marco passo năo! Mas se năo ê

Com desejos sonhados que me faço

Feliz, o excesso de vitalidade

Do esplrito é com eles que abre a vấlvula

Por onde escoa o inútil excessivo;

Pois afastando o céu de junto à Terra,

Tarde incomensurável, me permites,

Qual jaburus-moleques de passagem,

Lançar bem alto nos espaços essa

Mentirada gentil do que me falta.

A meditaçăo feita durante o rodar do automóvel termina com duas alusర̋es que resumem bem o movimento do poema entre os dois planos (sonhado e real; céu e terra). Chegando o passeante vê a máquina de beneficiar café marca Săo Paulo ainda arfando do trabalho, como um animal. Mas contrastando com este traço da nossa era mecanizada, no alto do espigăo é a velha lua romântica de sempre que sanciona o devaneio, porque favorece a transfiguração da realidade pela poesia. E para situar no modernismo a sua apariçăo, ela é comparada a um gaviăo empoleirado na árvore seca:

Ciao, tarde. Estou chegando. É quase noite.

Todo o céu já cinzou. Dependurada

$\mathrm{Na}$ rampa do terreiro a gaiolinha

Branca da máquina Săo Paulo inda arfa,

As tulhas de café desentulhando.

Pelo ar um lusco-fusco brusco trila,

Serelepeando na baixa fria.

Bern no alto do espigăo, sobre um pau seco,

Ver um carancho, se empoleira a lua,

- Condescendente amiga das metáforas...

20 thulo inicial do poema tol Tarde te quero bem", como se vo na citade carta a Manuel Bandoira. 
A esq., "Retrato de Mário de Andrade"; à dir., "Perfil do Mário de Andrade", de Dimitri Ismelilovitch; ambos de 1937 e ambos carvấo sobre papel

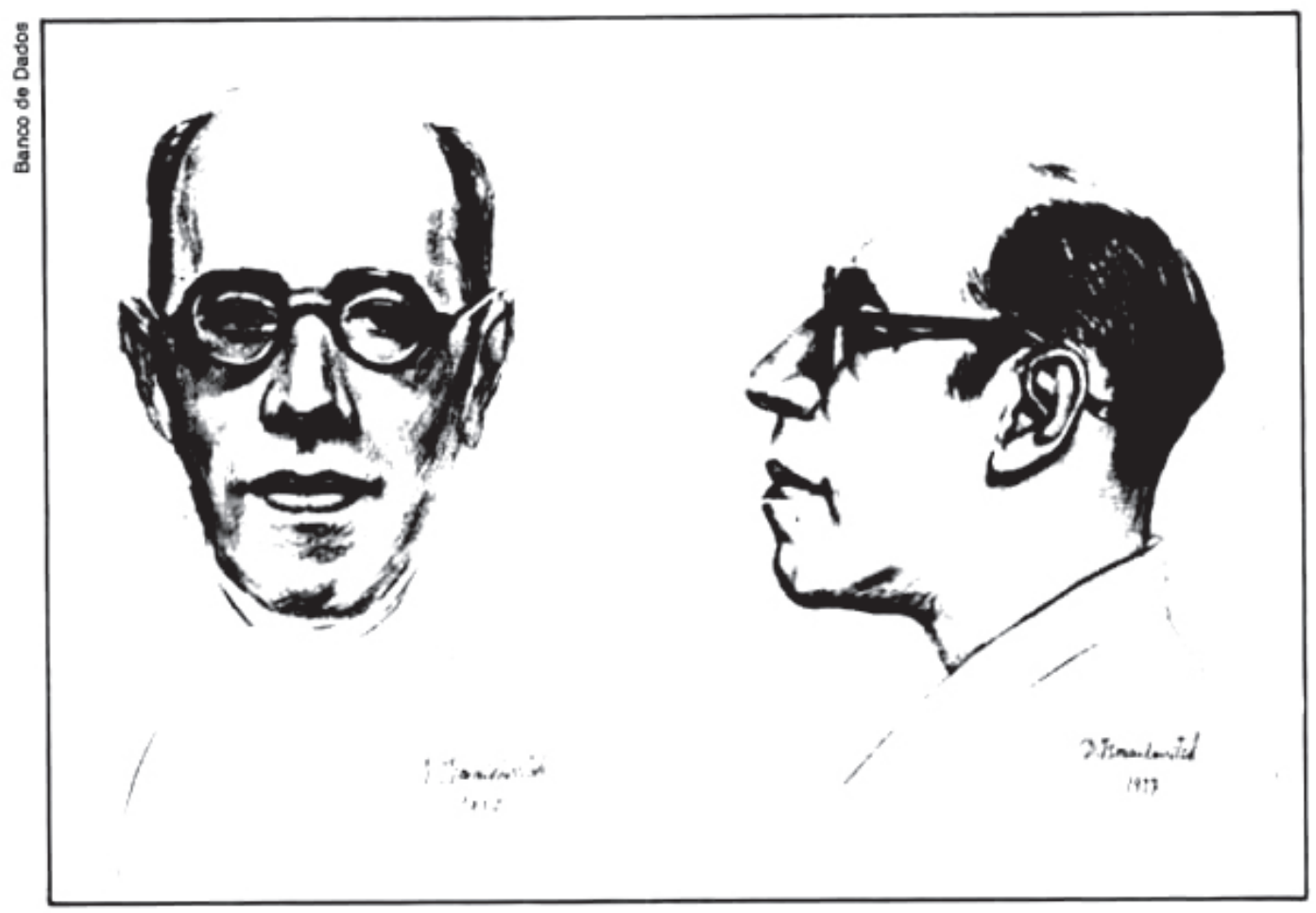

5.

Nesta descriçăo crfica tentei seguir a indicaçăo do poeta na carta a Manuel Bandeira, quando diz que o seu intuito foi fazer um "poema poesia construído com o pensamento condicionando o lirismo". Por isso foi preciso indicar o caminho da meditaçăo, em torno da qual se organiza o significado.

"Louvaçăo da tarde" mostra como o sonho-devaneio promove a fuga provisória do real e corno nasce dele o sonho-construçăo, que é o processo de que resulta a obra literária. Esta é sonho, porque deriva da fantasia; mas ê realidade, porque importa num ato positivo de fatura. A obrafeita liga o mundo da fantasia (tarde) ao mundo real, mostrando que săo solidários e interdependentes. Por isso "Louvaçăo da tarde" é uma oscilaçăo constante entre eles e desse jogo vai surgindo o poema. Quando o poeta chega de volta a casa da fazenda, a tarde (isto é, o devaneio) acabou; mas o poema está pronto (ou seja, a açáo criadora se realizou). Com efeito, ao mesmo tempo que o poeta descreve este processo o poema se constroi. E nós lembramos o final de $E m$ busca do tempo perdido, quando o Narrador, depois de tantos volumes, diz ter encontrado afinal a maneira de escrever o livro projetado. Ora, na verdade este está pronto, porque foi se construindo durante a indagaçăo, $\Theta$ a revelaçăo da chave que permitirá o seu inf́cio correto és o seu ponto final. Assim, em "Louvaçăo da tarde", quando o poeta dâ por encerrado o inútil do sonho, o necessário da obra está pronto.

Percebemos entăo que o poema assenta sobre uma base de paradoxos, porque a tarde ê devaneio gratuito, mas reservatơrio de trabalho; ê repouso e es construçăo. O movimento da fatura reúne os dois pólos e extrai delas a unidade pela fusăo dos contrários, que săo complementares. Este paradoxo afina com o da forma $e$ o do gênero: um poema moderno feito em decassnabos; a "meditaçăo" reinventada para exprimir uma situaçăo atual.

Paradoxo talvez mais importante do ponto de vista de uma estética do modernismo é o que contrapóe o automovel, instrumento da velocidade, à quietude vesperal do devaneio. Mas aqui, em vez de destruf-la pela rapidez do percurso ele ajuda a construf-la. Neste poema, tudo o que o futurismo queria revogar está no cerne do discurso, e em lugar da velocidade domesticar o mundo é o mundo que domestica a velocidade, submetendo-a ao ritmo natural. $\mathrm{O}$ automovel perde caracter'sticas de máquina e adquire um toque de vida, facilitando a "citaçăo" (quase parodica) dos traços românticos. E os dois momentos históricos se enlaçam, porque o tema de "Louvaçăo da tarde" parece transcender o tempo, na medida em que encarna tambérn o andamento da produçăo literâria. 